\title{
The determinants of the boundary-
} spanning functions of Japanese selfinitiated expatriates in Japanese subsidiaries in China: individual skills and human resource management

\section{Article}

Accepted Version

Creative Commons: Attribution-Noncommercial-No Derivative Works 4.0

Furusawa, M. and Brewster, C. (2019) The determinants of the boundary-spanning functions of Japanese self-initiated expatriates in Japanese subsidiaries in China: individual skills and human resource management. Journal of International Management, 25 (4). 100674. ISSN 1075-4253 doi: https://doi.org/10.1016/j.intman.2019.05.001 Available at https://centaur.reading.ac.uk/83707/

It is advisable to refer to the publisher's version if you intend to cite from the work. See Guidance on citing.

To link to this article DOI: http://dx.doi.org/10.1016/j.intman.2019.05.001

Publisher: Elsevier

All outputs in CentAUR are protected by Intellectual Property Rights law, including copyright law. Copyright and IPR is retained by the creators or other copyright holders. Terms and conditions for use of this material are defined in the End User Agreement. 


\section{www.reading.ac.uk/centaur}

\section{CentAUR}

Central Archive at the University of Reading

Reading's research outputs online 


\title{
The determinants of the boundary-spanning functions of Japanese self-initiated expatriates in Japanese subsidiaries in China: \\ Individual skills and human resource management
}

\begin{abstract}
:
Self-initiated expatriates (SIEs) who work for a subsidiary of a multinational enterprise from their country of origin and hence are familiar with both countries' language and culture can be expected to act as boundary-spanners between the assigned expatriates sent from the parent country and host country nationals, and between the headquarters and the subsidiary. We develop a new model of boundary-spanning that encompasses both individual and organizational antecedents and validate the model using survey data from Japanese-affiliated companies in China. We find that familiarity with Chinese language and culture and the potential dual allegiance of SIEs contribute to enhancing their boundary-spanning behavior. We also find that relationships of trust among the parties concerned (social capital) and global career opportunities for such self-initiated expatriates (geocentric staffing) have positive influences on their dual allegiance. Finally, normative and systems integration of human resource management are associated with increasing levels of social capital and geocentric staffing.
\end{abstract}

\section{Key words:}

Self-initiated expatriates, boundary-spanning functions, social capital, geocentric staffing, dual allegiance, Japanese-affiliated companies in China 


\section{Introduction}

Multinational enterprises (MNEs) are seeking new human resource management (HRM) alternatives to assigning parent country expatriates (PCNs) or host country nationals (HCNs) to run their foreign subsidiaries. Assigned expatriates understand headquarters but are expensive and know little of the host context: HCNs are cheaper but understand little about headquarters objectives or systems of working. In attempts to maintain the advantages of PCNs while reducing their disadvantages (Collings and Isichei, 2018; Collings et al., 2007), MNEs have begun to use self-initiated expatriates (SIEs) (Andresen et al., 2012; Vaiman and Haslberger, 2013). If they are from the home country then they have some of the advantages of assigned expatriates, but at much less cost, and they will know more about the host country. They are thus in a position to act as boundary-spanners.

SIEs are defined as individuals who decide on their own initiative to live and work in foreign countries (Suutari and Brewster, 2000). For MNEs, SIEs in their overseas subsidiaries are locally hired and many of them share their nationality with the organization that hires them. Thus, for example, Japanese SIEs often find themselves working for Japanese MNEs. Although they are hired as locals, and therefore are much cheaper than assigned expatriates, such employees can be expected to act as boundaryspanners between assigned expatriates from the parent country and local staff as well as between the headquarters and the subsidiary because of their familiarity with both countries' language and culture (Harzing et al., 2011).

We explore both individual and organizational factors that contribute to these boundaryspanning roles, using the example of Japanese SIEs in Japanese-affiliated companies in China - the country where Japanese MNEs have the largest number of overseas subsidiaries. While there have been studies of Western expatriates in China (e. g., Selmer, 2006; Wang and Nayir, 2006), there has been comparatively little on Japanese expatriates there (though see Gamble, 2010), and even less on Japanese self-initiated expatriates. The studies there have been of Japanese SIEs have analyzed them mainly from the perspective of the individual, examining such issues as motivation to expatriate, life-styles and values, and gender-related problems (Sakai, 2004; Thang et al., 2006) rather than an organizational perspective. We add to this limited management literature on Japanese SIEs by addressing both the individual and organizational antecedents of effective boundary-spanning.

The article takes the following form. First, we review relevant literature on self-initiated 
expatriates, boundary-spanning, and global mindsets or dual allegiance, and discuss the SIEs' potential value as boundary-spanners, as well as the importance of both individual skill-sets and organizational human resource management policies to enhance the boundary-spanning functions of SIEs. From that review, we develop hypotheses and a model of the antecedents of their boundary-spanning roles. Then, we explain our methodology and present our findings. Finally, we draw out the implications of the findings for our understanding of international human resource management and for practitioners.

\section{Self-initiated expatriates as boundary-spanners}

\section{1. SIEs as an IHRM option}

Studies of international human resource management in multinational enterprises have centered on issues concerning the expatriation of parent country nationals or assigned expatriates versus the development and utilization of host country nationals (Harzing and Pinnington, 2011; Martin and Bartolk, 2003; Rui and Shipman, 2017; Stahl et al., 2012). Although successful management of assigned expatriates makes positive contributions to organizational objectives, there are also drawbacks: Chief among these is the cost. AEs are very expensive (Bonache and Pla-Barber, 2005; Bonache and Stirpe, 2012). They may also have difficulties in adapting themselves to their new environment. Family adjustment, dual-career issues, or education for children can be troublesome as well (Haslberger and Brewster, 2008; Lazavora et al., 2010). Moreover, the reintegration of former expatriates at the end of their global assignment cycle can also be problematic (Kraimer et al. 2016).

The obvious alternative, relying on local managers and specialists, ('localization'), also involves potential problems, such as a possible lack of capability and of global perspectives on the part of local managers, and difficulties in coordination and communication between the headquarters and overseas subsidiaries (Collings et al., 2007). Consequently, companies may have to invest a lot of money and time in the development of such local employees, which could offset any advantages in costs. And these locals, having increased their value, are more likely to leave the company and move to a competitor (Khatri et al., 2001; Selmer, 2004; Tymon et al., 2010).

In the circumstances, MNEs are becoming increasingly aware of other options (Collings and Isichei, 2018; Harvey et al., 2011). In particular, the hiring of self-initiated expatriates from the home country who are already in the host country, is increasingly seen as a useful 
'third way' beyond the assigned expatriate/ host country national dichotomy (Andresen et al., 2012; Vaiman and Haslberger, 2013).

Parent country nationals working as SIEs in the foreign country can be hired into the overseas subsidiary of an MNE as 'local staff', so they are considerably cheaper than AEs. In addition, they are more likely to be internationally oriented and to stay significantly longer in the host country on average (Doherty et al., 2011; Suutari et al., 2018), though their motives for working abroad are diffuse: a desire for international experience, attractive job conditions, family ties, and poor labor markets in their home countries (Doherty et al., 2011; Froese, 2012). Some of them may also be bilingual/ bicultural persons who are proficient in more than one language and have internalized more than one cultural schema (Furusawa and Brewster, 2015; Harzing et al., 2011). SIEs tend to be more motivated to interact with host country nationals, and to understand the local culture (Mäkelä and Suutari, 2013; Peltokorpi and Froese, 2012). For instance, research in Japan shows that SIEs spend longer in the country and are more fluent in Japanese than AEs, which is related to significant differences in cross cultural adjustment between the two groups (Peltokopi and Froese, 2012). By contrast, the pre-determined length of an AEs' assignment negatively affects their motivation to learn the host country's language and culture (Hippler et al., 2015; Peltokorpi and Froese, 2012). According to a survey by the Japan Institute of Labour (2003), 94.6\% of the predetermined assignment period for Japanese AEs fall within the 3 - 5 years' range. They are sent abroad and repatriated to Japan as a part of the company-wide rotation programs. So SIEs are likely to have more potential for being bilingual and bicultural than AEs.

\section{2. Boundary-spanners in MNEs}

Overseas subsidiaries of MNEs are embedded in local host country contexts that differ from those of their home country. At the same time, they are also embedded in their global corporate networks. Such 'dual embeddedness' creates complex and implicit boundaries inside the company due to geographical, institutional, cultural, and linguistic diversity (Schotter et al., 2017): MNEs have been described as bundles of different types of boundaries (Carlile, 2004: 566). Boundaries bring about both division and identification which could lead to an 'us and them' or 'in-group and out-group' mentality (Schotter et al., 2017: 407). It is critical for MNEs to navigate their internal boundaries or crosscultural interfaces in order to benefit from their 'multi-nationality' (Barner-Rasmussen et al., 2014; Hayashi, 1994; Schotter et al., 2017). 
In general, language and culture, which are interrelated, are key sources of friction for the management of MNEs (Barner-Rasmussen et al., 2014; Brannen, 2004). So, MNEs require boundary-spanning employees (Kane and Levina, 2017; Schotter and Abdelzaher, 2013). Boundary-spanners are defined as individuals who are perceived by other members of both their own in-group and/ or relevant out-groups to engage in and facilitate significant interactions between the two groups (Barner-Rasmussen et al., 2014: 887). Birkinshaw et al. (2017: 424) define boundary-spanning as a specialized function that seeks opportunities to mediate the flow of information between relevant actors in an organizational unit and its task environment. Specifically, Schotter et al. (2017: 404) recognize boundary-spanning in MNEs as a set of communication and coordination activities performed by individuals within an organization to integrate activities across multiple cultural, institutional and organizational contexts. They propose 'a rubber band model' where boundary-spanners, like rubber bands, connect two organizational subunits while providing enough flexibility to independently respond to diverse forces when necessary. Roberts and Beamish (2017: 512) also insist that the goal of global boundaryspanning is to help organizational members progressively learn from foreign knowledge practices and engage in meaningful ways with foreign stakeholders. They develop 'a scaffolding model' of boundary-spanning which frames the cognitive, relational, and material supports that boundary-spanners enact so that organizational members engage in practices that allow for the awareness, capacity building, and commitment to adoption of foreign practices. In short, boundary-spanners are a means of improving linkages (Schotter and Beamish, 2011: 253).

Boundary-spanners are more valuable for MNEs from homogeneous societies such as Japan (Fernandez and Barr, 1993; Yoshino, 1976), as illustrated by Okamoto and Teo (2012): Their survey of Japanese-affiliated companies in Australia shows that Japanese SIEs, who are familiar with the cultures of both Japan and Australia through their experience of living and working in those countries, assist communication between assigned expatriates and host country nationals by playing the role of 'cultural mediators'.

These boundary-spanning functions are even more important for Japanese subsidiaries in China, where $45 \%$ of the total Japanese-affiliated companies in foreign countries are located (Ministry of Foreign Affairs of Japan, 2017), as numerous studies (e.g., Kosonen et al., 2012; Taura, 2005) report significant HRM challenges there. The communication gap between Japanese AEs and host country nationals is a serious issue because of 
differences in cultural schemas (Taura, 2005). In addition, Japanese subsidiaries have been suffering from a weak identification with the enterprise and a high turn-over rate among Chinese employees which could be related to their work culture or values (Hong et al., 2006; Kosonen et al., 2012; Taura, 2005). From the other perspective, the Chinese business environment, influenced by the Chinese language, culture, and political system, is as difficult to comprehend for Japanese assigned expatriates living there for a short time, as it is for Western expatriates (Murray and Fu, 2016; Varma et al., 2011). Perhaps consequently, the levels of cross-cultural adjustment and job performance of Japanese AEs in China are relatively lower than those of Japanese expatriates in other countries (Furusawa and Brewster, 2016). So Japanese subsidiaries in China face HRM challenges for both Chinese staff and Japanese AEs. Boundary-spanners may ameliorate these problems.

\section{3. Hypotheses development}

The familiarity of home country SIEs with the language and culture of both parent and host countries is likely to make them ideal bridge persons or boundary-spanners (Harzing et al., 2011). Their linguistic and cultural skills are important sources of common cognitive ground and thus contribute to a better understanding of the codes of conduct, systems of meaning, and knowledge base of others, and are significantly associated with the extent to which individual employees perform boundary-spanning functions of exchanging, linking, facilitating, and intervening (Barner-Rasmussen et al., 2014: 888889). So bilingual and bicultural SIEs might be expected to act as boundary-spanners. Hence, our first hypothesis.

Hypothesis 1: Familiarity with local language and culture enhances the boundary-spanning functions of SIEs.

However, not every bilingual and bicultural individual will be equally effective as a boundary-spanner (Schotter et al., 2017: 413). The management of MNEs is filled with complexity and contradictions which arise from cultural diversity and strategic dilemmas such as local responsiveness versus global integration and representing the multiple, sometimes contradictory, interests of diverse group can be stressful (Kane and Levina, 2017: 543). Home country SIEs playing boundary-spanning roles may experience role conflict, due to their multiple and conflicting activities which could be related to their own dual embeddedness in the contexts of both parent and host countries (Vora et al., 2007). Such role conflict may be ameliorated by organizational policies, as Schotter et al. (2017) argue: The characteristics of the individual actors and the organizational context 
determine both the nature of boundary spanning actions and its effectiveness. To date, however, the literature has not clearly indicated how we can understand the organizational (or human resource management) factors that would enhance SIEs' boundary-spanning roles. We aim to address this research gap by developing an integrative model of antecedents to the boundary-spanning behavior of SIEs from both individual and organizational perspectives.

The complexity and contradictions embedded in MNEs cannot be resolved by structure but need to be built into employees' way of thinking (Bartlett and Ghoshal, 1989; Evans, 1992; Kedia and Mukherji, 1999). It has been argued that a 'global mindset' is required to span MNE boundaries successfully. A global mindset is a state of mind or 'way of being', rather than a set of skills, that predisposes individuals to deal constructively with competing local versus global priorities rather than advocating one dimension at the expense of the other (Arora et al., 2004; Evans et al., 2002, 2010). Gupta and Govindarajan (2002) define a global mindset as comprising high differentiation and high integration combined with an openness to diversity across cultures and markets, with a propensity and ability to synthesize across this diversity. There are different, though complementary, perspectives on the concept of global mindset (Evans et al., 2002): Psychological, focused on the development of managers (Levy et al., 2007; Scullion and Collings, 2006); and Strategic, taking an organizational viewpoint and concerned with balancing local responsiveness and global integration (Evans et al., 2010). Individuals with the highest levels of global mindset are able to bridge boundaries (Levy et al., 2007; Vora et al., 2007). There is, however, much debate about the precise nature of a global mindset and whether and how it can be measured (Bucker and Poutsma, 2010; Levy, et al., 2007) so we use the strategic notion of global mindset or dual allegiance to home head office and subsidiary, and hypothesize:

Hypothesis 2: A dual allegiance enhances the boundary-spanning functions of SIEs.

Dual allegiance is only likely to occur in two contexts. One is where there is a 'relationship of trust' among the parties concerned. Trust is at the core of the relational dimension of social capital, a major component of dual allegiance (Javidan and Teagarden, 2011). Trust is a psychological state comprising the intention to accept vulnerability based upon positive expectations of the intentions or behavior of another (Rousseau et al., 1998: 395). As trust reduces uncertainty and enhances cooperation and openness of communication, it is an important predictor of the general effectiveness of the relationship 
(Gillespie and Mann, 2004). Therefore, social capital or a trusting relationship could be expected to serve as a horizontal coordination mechanism when SIEs attempt to span boundaries at MNEs from the perspective of total optimization. Hayashi $(1985,1994)$ emphasizes that people have to acquire legitimacy as a trustworthy participant from at least one group of members of each of the two countries in order to help nurture mutual understanding in the foreign subsidiaries of MNEs by 'culturally translating' the information, knowledge, and values exchanged across the two cultures.

The other necessary context is 'global career opportunities' for SIEs. International assignments give people a chance to broaden their horizons and appreciate diversity, while developing the network of weak ties that constitute the nervous system of the firm (Evans et al., 2002). If the global career opportunities for SIEs are limited, they may not be motivated to develop a dual allegiance to the local and the global. Research indicates that SIEs are often, because of status differences, in a less beneficial organizational career situation than AEs, may be underemployed and feel their psychological contract is not positive (Doherty and Dickmann, 2012, 2013; Lee, 2005; Peltokorpi and Froese, 2012). Any resulting lack of dual allegiance makes it more likely that overseas subsidiaries behave as a medley of stand-alone companies, undermining the worldwide learning capability of the MNE (Bartlett and Ghoshal, 1989, 1995; Furusawa, 2014). Accordingly, we argue that:

Hypothesis 3: Relationships of trust and global career opportunities contribute to the dual allegiance of SIEs.

In relation to trust and global career opportunities, an empirical survey of Japanese MNEs by Furusawa et al. (2016) suggests that practices of normative and systems integration are associated with increasing levels of social capital and geocentric staffing respectively. Normative integration refers to worldwide socialization by disseminating a global corporate philosophy throughout the company. Globally shared values can be expected to encourage the trust that is essential for effective lateral coordination and to act as a 'psychological glue' to bind different persons together in MNEs (Evans et al., 2010; Gillespie and Mann, 2004). Normative integration requires recruitment and selection, induction and training programs to be based on a clear corporate philosophy or set of values, selective promotion of individuals who have internalized the core values of the organization, corporate ceremonies and symbols, and so on (Evans et al., 2010; Furusawa, 2008). Regular employee opinion surveys such as the 'global credo survey' at Johnson \& Johnson can be utilized to check and ensure the dissemination of the corporate philosophy 
(Furusawa, 2008). Expatriation, global project teams or task forces, overseas business trips and face-to-face communication with the executives of the headquarters can also be effective tools for promoting the process of transnational socialization through informal human networks (Fang et al., 2010; Mäkelä and Brewster, 2009; Yagi and Kleinberg, 2011).

Systems integration involves globally integrated HRM systems (Furusawa, 2014; Furusawa et al., 2016). The fundamental advantage of multinational companies over domestic ones lies in the international availability of capable human resources (Evans et al., 2010; Thomas \& Lazarova, 2014). These advantageous, geocentric (Perlmutter, 1969) or transnational (Bartlett and Ghoshal, 1989, 1995), orientations assume situations wherein ideas are exchanged, and human resources are utilized, across borders to create and diffuse innovation and knowledge on a global basis. In attempts to develop these organizational capabilities, global headquarters implement systems to make the best use of their competent employees around the world. The consistency of HRM practices across the globe brought about by systems integration creates cross-border equity and comparability, and alignment of systems internationally to facilitate an internal labor market with global career opportunities for local employees, including SIEs (Farndale et al., 2008). Systems integration encompasses globally standardised systems of job grades, personnel appraisals, and compensation (Furusawa, 2008; Hanada, 1988), global HRM databases (Doz et al., 2001) and global talent management and succession planning programs (Scullion and Collings, 2006), uniform measures of global competency or leadership, clearly indicated career paths for high-potentials, and global job-posting systems. Hence, we propose two further hypotheses:

Hypothesis 4: There is a positive association between practices for normative integration in international HRM and relationships of trust between SIEs, local employees, and headquarters.

Hypothesis 5: There is a positive association between practices for systems integration in international HRM and global career opportunities for SIEs.

We can summarize the discussion so far in a framework of analysis (Figure 1). 
Figure 1: Framework of analysis

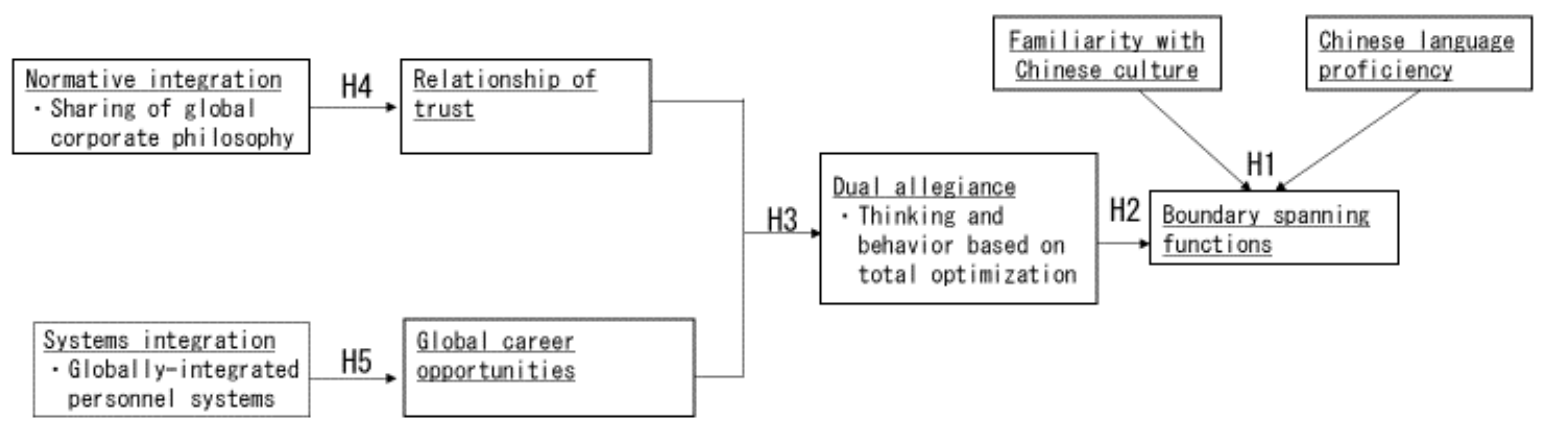

\section{Methodology}

\section{1. Sample}

Our evidence is drawn from subsidiaries of Japanese MNEs in China. Our sample is drawn from the corporate clients of Lead-S Corporation, one of the largest Japaneseaffiliated human resource consultancies operating in the region of Shanghai and the surrounding Jiangsu Province in China. Given the regional variations in the Chinese business environment and labor market (Teng et al., 2017), we narrowed down the target area of our research to this region, which is the hottest investment spot for Japanese multinationals. By doing so, we aimed to minimize the regional effects on the results of our research.

The questionnaire, prepared in Japanese, was emailed to the top subsidiary managers in our target group and an assigned Japanese expatriate executive answered it in each company. Respondents returned their completed questionnaires directly to us. The majority of the respondents are the Presidents of the Chinese subsidiary. Responses were obtained from 188 different subsidiaries. Lead-S Corporation were unwilling to provide a full list of their clients, so we cannot calculate response rates, though the company suggested that the responses cover some $15 \%$ of their corporate clients. Nearly $73 \%$ of them were in manufacturing, and $87 \%$ were wholly-owned subsidiaries of Japanese 
companies. $81 \%$ of the parent companies of respondents were categorized as 'large company' by the standards of the Companies Act in Japan, which means they mostly represent a cohort of leading Japanese MNEs.

Fifty $(27 \%)$ of the respondents employ Japanese self-initiated expatriates. The ratio in non-manufacturing companies was higher than that in manufacturing businesses (43\% vs. 20\%: $0.1 \%$ level of significance), perhaps because of the fact that $70 \%$ of the respondents have Japanese-affiliates and/ or Japanese individuals in China as their major customers, and the general perception that non-manufacturing businesses are more dependent on human resources and require subtler or more complicated communication skills than manufacturing.

\section{2. Measures}

To test our hypotheses, we asked our 50 respondents employing Japanese SIEs about the following issues. All the questions used a 5-point Likert scale.

With regard to Chinese language proficiency, familiarity with Chinese culture, dual allegiance, boundary-spanning functions, and trust of Japanese SIEs, we asked the companies to evaluate each SIE individually. Where they employed four or more SIEs, they were requested to select 'a maximum of three' of them in the highest positions (or where they were in equivalent positions, to select them according to length of service). We collected the evaluations of 91 Japanese SIEs which cover $57 \%$ of the total Japanese SIEs employed. Their fluency in Chinese was evaluated from the facets of speaking, reading, and writing (5=capable without any problems, $4=$ mostly fluent, $3=$ a little bit, $2=$ hardly at all, 1=not at all). Respondents (AEs) self-reported their own Chinese language proficiency using the same scale. Familiarity with Chinese culture was operationalized by asking how much each SIE supports the cross-cultural adjustment of Japanese assigned expatriates in a business setting and in daily living (5=exactly correct, $4=$ correct, if anything, $3=$ unsure, $2=$ incorrect, if anything, $1=$ entirely incorrect). To check dual allegiance, we asked whether the respondents thought each Japanese SIE thinks and behaves with a perspective of total optimization based on the global business strategy. To test the boundary-spanning functions of Japanese SIEs, we focused on the two major cross-cultural interfaces which could be influenced by individual skills and/ or human resource management: The interface between Japanese assigned expatriates and Chinese staff in the Chinese subsidiary, and that between the Japanese-affiliates in China and the headquarters in Japan. Respondents were asked about the extent to which each SIE acts 
as a bridge between Japanese AEs and Chinese employees as well as between the Chinese operation and the headquarters in Japan. Concerning trust, we asked about the relations between Japanese SIEs and Japanese AEs, Chinese staff, and the headquarters in Japan.

For global career opportunities, we asked respondents about the international transfer opportunities for SIEs, namely the chances of being given assigned expatriate status or permanent transfer to the headquarters, temporary transfer to the headquarters, and permanent or temporary transfer to other affiliates abroad or in China.

Practices for normative integration and systems integration were operationalized through eight questions for each by adapting Furusawa et al. (2016), inquiring about the extent to which the company used each practice. So for normative integration, we asked about means of disseminating the corporate philosophy to Japanese SIEs, examining the use of measures such as recognition and corporate events, recruitment and selection, induction and training, personnel evaluation, business trips to Japan, meetings with executives from the headquarters, employee satisfaction and/ or corporate culture surveys, and temporary reverse-transfer to the headquarters and/ or participation in cross-border projects. For systems integration, we explored the degrees of standardization in compensation systems, personnel appraisals, job grades, and competency and/ or leadership models, and we also asked about practices like succession planning and/ or talent management, clearly indicated career paths for SIEs, global sharing of HRM information about SIEs, and global job-posting.

Multiple regression analyses were applied to test the hypotheses. We initially tried structural equation modelling. However, almost certainly as a result of the small sample size in comparison with the number of constructs in our model, the indicators of goodness-of-fit were not strong. It seemed incorrect for us to manipulate our constructs in order to achieve fit. We therefore judged that multiple regression analysis is best suited for verifying the hypotheses, despite the danger that the method involves potential risk of ignoring indirect effects of variables and failing to control for endogeneity issues. The analyses gave us robust results and all VIF scores were well below 2.00 suggesting that multicollinearity was not a major problem in our study.

\subsection{Follow-up interview survey}

To enrich and triangulate our data, we carried out qualitative interviews with Japanese AEs and SIEs in Japanese-affiliated companies in China. The interviewees were selected 
from the respondents of our questionnaire survey in consideration of balance of type of business, type of ownership, gender, and position. There were 16 informants in total (AEs=8; SIEs=8). Each meeting lasted 1 to 2 hours and took the form of a semi-structured interview. The qualitative data was categorized and processed by using the KJ (Kawakita Jiro)-method.

The interviews tended to confirm the results of the survey, and comments from the interviewees enable us to enrich and triangulate the quantitative data with statements from those involved. Interviews were carried out in Japanese: The comments below have been translated into English by the first-named author. Due to the anonymity agreed with our respondents, we refrained from disclosing details of their antecedents in this paper.

\section{Findings}

\section{1. Descriptive statistics}

Table 1 shows the linguistic proficiency in Chinese of Japanese assigned expatriates (AEs) and self-initiated expatriates (SIEs). The mean scores of SIEs were significantly higher than those of the AEs in all three aspects of Chinese fluency at the $0.1 \%$ significance level.

Table 1: Chinese language proficiency of Japanese AEs and SIEs

\begin{tabular}{|l|l|l|l|}
\hline & Japanese AEs & Japanese SIEs & t-value \\
\hline (1) Speaking & 3.18 & 4.07 & $-5.677 * * *$ \\
\hline (2) Reading & 3.27 & 4.10 & $-5.612 * * *$ \\
\hline (3)Writing & 2.94 & 3.71 & $-4.732 * * *$ \\
\hline
\end{tabular}

Notes. Scores in the table are the means of answers on 5-point Likert-scales ( $5=$ capable without any problems, $4=$ mostly fluent, $3=$ a little bit, $2=$ hardly at all, $1=$ not at all). $* * *: \mathrm{p}<0.001$.

The mean values of SIEs' familiarity with Chinese culture operationalized by their support for cross cultural adjustment of AEs in the business setting and daily living were 2.68 and 2.44 respectively. The average score of their dual allegiance was 3.11. In regard to the boundary-spanning functions of Japanese SIEs, the mean score of 'a bridge person between Japanese AEs and Chinese staff' was 3.33 whereas that of 'a bridge person between the Chinese operation and the headquarters in Japan' was 3.03 (Table 2). 
Table 2: Familiarity with Chinese culture, dual allegiance, and boundary-spanning functions

\begin{tabular}{|c|c|c|}
\hline & Total & SD \\
\hline \multicolumn{3}{|l|}{ Familiarity with Chinese culture } \\
\hline $\begin{array}{l}\text { (1) Japanese SIEs support cross-cultural adjustment of Japanese AEs } \\
\text { in business settings. }\end{array}$ & 2.68 & 1.29 \\
\hline $\begin{array}{l}\text { (2)Japanese SIEs support cross-cultural adjustment of Japanese AEs } \\
\text { in daily living. }\end{array}$ & 2.44 & 1.21 \\
\hline \multicolumn{3}{|l|}{ Dual allegiance } \\
\hline $\begin{array}{l}\text { (1) Japanese SIEs think and behave with the perspective of total } \\
\text { optimization based on the global business strategy of the } \\
\text { headquarters in Japan. }\end{array}$ & 3.11 & 1.09 \\
\hline \multicolumn{3}{|l|}{ Boundary-spanning functions } \\
\hline $\begin{array}{l}\text { (1)Japanese self-initiated expatriates contribute as a bridge person } \\
\text { between cultures (languages and mindset) of Japanese assigned } \\
\text { expatriates and Chinese employees. }\end{array}$ & 3.33 & 1.25 \\
\hline $\begin{array}{l}\text { (2)Japanese self-initiated expatriates contribute as a bridge person } \\
\text { between the local operation and the headquarters in Japan. }\end{array}$ & 3.03 & 1.37 \\
\hline
\end{tabular}

Notes. Scores in the table are the means of answers on 5-point Likert-scales (5=exactly correct, $4=$ correct, if anything, $3=$ unsure, $2=$ incorrect, if anything, $1=$ entirely incorrect).

Our descriptive statistics also show that Japanese SIEs, on the whole, seem to build a relationship of trust with Japanese AEs, Chinese employees, and the headquarters in Japan. The mean scores were 4.24, 3.98, and 3.45 respectively. By contrast, all the means for global career opportunities were below 2.00 (Table 3).

Table 3: Relationship of trust and global career opportunities

\begin{tabular}{|c|c|c|}
\hline & Total & SD \\
\hline \multicolumn{3}{|l|}{ Relationship of trust } \\
\hline (1)Japanese SIEs build a relationship of trust with Japanese AEs. & 4.24 & 0.74 \\
\hline $\begin{array}{l}\text { (2) Japanese SIEs build a relationship of trust with Chinese } \\
\text { employees. }\end{array}$ & 3.98 & 0.73 \\
\hline $\begin{array}{l}\text { (3) Japanese SIEs build a relationship of trust with the headquarters } \\
\text { in Japan. }\end{array}$ & 3.45 & 1.15 \\
\hline Global career opportunities & & \\
\hline
\end{tabular}




\begin{tabular}{|l|l|l|}
\hline $\begin{array}{l}\text { (1)Expatriate status is often given to Japanese SIEs or they are often } \\
\text { transferred permanently to the headquarters in Japan. }\end{array}$ & 1.86 & 1.06 \\
\hline $\begin{array}{l}\text { (2) Japanese SIEs are often transferred temporarily to the } \\
\text { headquarters in Japan. }\end{array}$ & 1.57 & 0.79 \\
\hline $\begin{array}{l}\text { (3) Japanese SIEs are often transferred permanently or temporarily to } \\
\text { other affiliates abroad or those in China. }\end{array}$ & 1.61 & 0.89 \\
\hline
\end{tabular}

Notes. Scores in the table are the means of answers on 5-point Likert-scales ( $5=$ exactly correct, $4=$ correct, if anything, $3=$ unsure, $2=$ incorrect, if anything, $1=$ entirely incorrect).

The highest mean in practices for normative integration was 'Japanese SIEs are invited to attend meetings and/ or events with the executives from the headquarters when they visit China' (3.65) followed by 'there is a recognition program and/ or in-house events which reflect our corporate philosophy' (3.51) and 'when hiring Japanese SIEs locally, a recruitment policy is in place that includes the candidates' compatibility with our corporate philosophy (potential to accept our corporate philosophy) within the hiring criteria' (3.37). In contrast, all the mean scores of practices for systems integration were below 2.50 - scores for a standardized compensation system, personnel appraisals, and job grades were all below 2.00 (Table 4).

Table 4: Practices for normative and systems integration

\begin{tabular}{|c|c|c|c|c|c|}
\hline Normative integration & Total & SD & Systems integration & Total & SD \\
\hline $\begin{array}{l}\text { (1)There is a recognition program and/ or in- } \\
\text { house events which reflect our corporate } \\
\text { philosophy. }\end{array}$ & 3.51 & 1.16 & $\begin{array}{l}\text { (1) There are programs or systems such } \\
\text { as succession planning and/ or talent } \\
\text { management in place to list competent } \\
\text { Japanese SIEs at the headquarters in } \\
\text { Japan to develop and utilize them as } \\
\text { the future candidates for executive } \\
\text { positions. }\end{array}$ & 2.35 & 1.28 \\
\hline $\begin{array}{l}\text { (2)When hiring Japanese SIEs locally, such } \\
\text { recruitment policy is in place that includes the } \\
\text { candidates' compatibility with our corporate } \\
\text { philosophy (potentials to accept our corporate } \\
\text { philosophy) within the hiring criteria. }\end{array}$ & 3.37 & 1.13 & $\begin{array}{l}\text { (2)The career path is clearly presented } \\
\text { for competent Japanese SIEs. }\end{array}$ & 2.33 & 1.09 \\
\hline
\end{tabular}




\begin{tabular}{|c|c|c|c|c|c|}
\hline $\begin{array}{l}\text { (3) The training program of our corporate } \\
\text { philosophy is implemented for Japanese SIEs. }\end{array}$ & 3.14 & 1.28 & $\begin{array}{l}\text { (3) The personnel information (e.g., the } \\
\text { results of personnel evaluation) of } \\
\text { Japanese SIEs is shared with the } \\
\text { headquarters in Japan. }\end{array}$ & 2.12 & 1.27 \\
\hline $\begin{array}{l}\text { (4) Such personnel evaluation policy is in } \\
\text { place that incorporates the embodiment of our } \\
\text { corporate philosophy (the way of thinking and } \\
\text { behavior based on our corporate philosophy) } \\
\text { as a criterion to evaluate Japanese SIEs. }\end{array}$ & 3.02 & 1.13 & $\begin{array}{l}\text { (4) There is an in-house global job- } \\
\text { posting system in place which allows } \\
\text { Japanese SIEs to apply. }\end{array}$ & 1.49 & 0.82 \\
\hline $\begin{array}{l}\text { (5) Japanese SIEs are given opportunities to go } \\
\text { on a business trip to Japan to get in touch with } \\
\text { key persons at the headquarters in Japan. }\end{array}$ & 3.18 & 1.25 & $\begin{array}{l}\text { (5) The compensation system is } \\
\text { standardized worldwide. }\end{array}$ & 1.38 & 0.73 \\
\hline $\begin{array}{l}\text { 6) Japanese SIEs are invited to attend } \\
\text { meetings and/ or events with the executives } \\
\text { from the headquarters when they visit China. }\end{array}$ & 3.65 & 1.20 & $\begin{array}{l}\text { (6) The personnel evaluation system is } \\
\text { standardized worldwide. }\end{array}$ & 1.61 & 0.89 \\
\hline $\begin{array}{l}\text { (7)The level of infiltration of our corporate } \\
\text { philosophy among Japanese SIEs is checked } \\
\text { through regular employee satisfaction and/ or } \\
\text { corporate culture surveys. }\end{array}$ & 2.41 & 1.19 & $\begin{array}{l}\text { (7) The grading system such as ability- } \\
\text { based grade system or job grade } \\
\text { system for employees is standardized } \\
\text { worldwide. }\end{array}$ & 1.57 & 0.87 \\
\hline $\begin{array}{l}\text { 8) Japanese SIEs are encouraged to } \\
\text { understand our corporate philosophy from } \\
\text { experiences such as temporary reverse- } \\
\text { transfer to the headquarters in Japan and/ or } \\
\text { participation in cross-border projects. }\end{array}$ & 2.35 & 1.18 & $\begin{array}{l}\text { 8) There are globally integrated } \\
\text { competency and/ or leadership models } \\
\text { in place. }\end{array}$ & 2.02 & 1.23 \\
\hline
\end{tabular}

Notes. Scores in the table are the means of answers on 5-point Likert-scales (5=exactly correct, $4=$ correct, if anything, $3=$ unsure, $2=$ =incorrect, if anything, $1=$ entirely incorrect).

\section{2. Multiple regression analyses and the follow-up interview survey results}

Multiple regression analyses were applied to test the hypotheses ${ }^{\mathrm{i}}$. We controlled for the type of business (manufacturing vs. non-manufacturing), the type of ownership (whollyowned vs. joint venture), gender (male vs. female), and position (non-managerial vs. managerial) of SIEs. Among control variables, the type of ownership and gender were 
related to the bridge between the local operation and the headquarters. As for independent variables, aggregated scores of three facets of 'Chinese language proficiency' $(\alpha=0.959)$ and those of 'familiarity with Chinese culture' $(\alpha=0.904)$ were positively related to 'the bridge between Japanese AEs and Chinese employees', though neither of the independent variables had a significant relationship with 'the bridge between the Chinese subsidiary and the headquarters in Japan' (Table 5). Hence, Hypothesis 1 was partially supported.

Our follow-up interview survey of Japanese AEs and SIEs confirms that SIEs can contribute as a bridge between Japanese AEs and Chinese employees at Japaneseaffiliated companies in China. Mr. A (AE, mfg.) said:

"The familiarity of our Japanese SIE manager with the Chinese language and culture is very valuable. He graduated from a university in China and his wife is Chinese. On the other hand, most Japanese AEs are not fluent in Chinese and stay in China only for 3-5 years. Under such circumstances, he supports crosscultural adjustment of AEs and acts as a boundary-spanner between AEs and local staff."

Mr. B (AE, mfg.) also recognized the value of Japanese SIEs:

"The headquarters in Japan do not necessarily dispatch Japanese AEs to China as Chinese business professionals. They usually work in China only for 3-5 years as a part of the company-wide rotation program. In contrast, our SIEs are more likely to stay longer in China and be fluent in Chinese. Therefore, they can play the role of bridge between Japanese AEs and Chinese employees."

Mr. C (SIE, mfg.) related the issue to high context communication style of Japanese people:

"Japanese-speaking Chinese employees can translate the words but cannot understand the delicate nuances of the orders from Japanese AEs. My strength is that I can 'read the air' as a native Japanese and then I communicate the details of the orders clearly to Chinese employees in Chinese. As I used to work as an $\mathrm{AE}$ at a Japanese-affiliated company in China and have been in China for more than 10 years, I am familiar with the work cultures of both Japan and China."

In a similar vein, Mr. D (SIE, non-mfg.) mentioned:

'Japanese-style 'tacit' or 'telepathic' communication does not work in China. While Japanese AEs expect Chinese staff to learn from their behavior, the local 
employees need more clear and concrete instructions from their Japanese bosses. As these communication problems arise in our daily operations very often, I coordinate the relations between the two groups and resolve the mutual misunderstanding as a bridge person."

Table 5: Determinants of boundary-spanning functions of Japanese SIEs

\begin{tabular}{|c|c|c|}
\hline & $\begin{array}{c}\text { Bridge between } \\
\text { Japanese AEs and } \\
\text { Chinese employees } \\
\beta \\
\end{array}$ & $\begin{array}{c}\text { Bridge between } \\
\text { the Chinese subsidiary and } \\
\text { the headquarters in Japan } \\
\beta\end{array}$ \\
\hline $\begin{array}{l}\text { Control variables } \\
\cdot \text { Type of business } \\
\quad(\mathrm{mfg} .=0, \text { non-mfg. }=1)\end{array}$ & 0.108 & 0.016 \\
\hline $\begin{array}{c}\text { Type of ownership } \\
\quad(\text { wholly-owned=0, } \\
\text { joint-venture=1) }\end{array}$ & 0.166 & $0.207 *$ \\
\hline $\begin{array}{l}\cdot \text { Gender } \\
\quad(\text { male }=0, \text { female }=1)\end{array}$ & 0.088 & $0.284^{* *}$ \\
\hline $\begin{array}{l}\cdot \text { Position } \\
\quad(\text { non-managerial=0, } \\
\quad \text { managerial=1) }\end{array}$ & 0.059 & -0.023 \\
\hline$\frac{\text { Independent variables }}{\text { - Chinese language proficiency }}$ & $0.352 * * *$ & -0.013 \\
\hline - Familiarity with Chinese culture & $0.458 * * *$ & 0.089 \\
\hline - Dual allegiance & $0.169^{*}$ & $0.482 * * *$ \\
\hline $\mathrm{R} 2$ & 0.615 & 0.435 \\
\hline $\mathrm{F}$ & $18.003 * * *$ & $8.705^{* * *}$ \\
\hline
\end{tabular}

In our multiple regression analyses, 'dual allegiance' was positively associated with both 'the bridge between Japanese AEs and Chinese employees' and 'the bridge between the Chinese subsidiary and the headquarters in Japan' (Table 5). So, Hypothesis 2 was supported.

Our interviews verified that dual allegiance is a key requirement for effective boundary 
spanning functions, but also that spanning the boundaries in MNEs can be stressful and challenging. Mr. E (SIE, non-mfg.) explained his role as a boundary-spanner as follows: "My value at this company is playing the function of a mediator between Japanese AEs and Chinese staff, as well as between Chinese operation and the Japanese headquarters. The role can be executed because I always think and behave from the perspective of total optimization."

Mr. F (SIE, mfg.) emphasized the advantages of SIEs:

"I think SIEs are potentially in a better position to develop a dual allegiance for boundary-spanning roles than AEs and HCNs. This is because SIEs are more likely to spend a longer time in the host country than AEs, whereas we (SIEs) share the same language and culture with the headquarters in Japan."

In contrast, Mr. G (SIE, non-mfg.) recalled bitter experiences as an SIE at his former workplace:

"I was on the horns of a dilemma between Japanese AEs and Chinese staff. I could not deal with mutually contradictory requirements from both sides and had too much work on my hands. As a result, I felt stressed out and quit the job."

Similarly, Mr. H (AE, non-mfg.) recognized the hardships of SIEs:

"Some SIEs find difficulty in developing and managing their subordinates [Chinese staff] because their boss [Japanese AE] leaves all the work to them. In some cases, SIEs are exploited by the company as utility low-cost Japanese employee. It might be difficult for such SIEs to develop a dual allegiance."

The statements above seem to suggest the importance of organizational context so that SIEs can foster a dual allegiance.

To test hypotheses 3, 4 and 5, we first conducted factor analyses to group the items of normative and systems integration as well as those of relationships of trust and global career opportunities (for likelihood method and promax rotation: see appendix). For normative integration, we extracted two factors with eigenvalues greater than 1.00 , explaining $65.9 \%$ of total variance. The first factor $(\alpha=0.829)$, comprised of socialization practices - recruitment, training, personnel evaluation, recognition, and in-house corporate culture surveys (the 'HRM cycle' approach) - and the second one $(\alpha=0.714)$, consisting of opportunities for face-to-face meetings with the headquarters executives, 
we named the 'interaction with HQ executives' approach.

Likewise, two clear factors with eigenvalues greater than 1.00 were extracted for systems integration, explaining $72.3 \%$ of total variance. The first factor or 'standardization' approach $(\alpha=0.835)$ comprised practices which covered global-wide systems of compensation, evaluation, and job grades, whereas the second one or 'career advancement opportunities' approach $(\alpha=0.764)$ included measures on succession planning and/ or talent management, clearly-indicated career paths, and global jobpostings for SIEs. The situations on the relationship of trust and global career opportunities were consolidated into 'social capital' $(\alpha=0.711)$ and 'geocentric staffing' $(\alpha=0.569)$ respectively.

In our statistical analyses, we tested the causal effects of relationships of trust/ global career opportunities on dual allegiance. As far as the control variables are concerned, the type of business, type of ownership, and position were related to the dependent variable (Table 6). As to independent variables, both 'social capital' (aggregated score of relationship of trust) and 'geocentric staffing' (aggregated score of global career opportunities) had positive influences on dual allegiance. Thus, Hypothesis 3 was supported.

Our interviewees pointed out the lack of trusting relationships and career anxiety as serious obstacles to a dual allegiance. Mr. B (AE, mfg.) commented on the relations with Chinese staff:

"When SIEs are expected to play the role of boundary-spanners, trusting relationships among the parties concerned are indispensable. However, as Japanese SIEs are usually paid higher than local staff, there could be a possibility of friction."

As for the relations with Japanese AEs, Mr. I (AE, non-mfg.) mentioned:

"There seems to exist mutual distrust between Japanese AEs and SIEs in some Japanese-affiliates in China. In such companies, Japanese AEs look down on the SIEs, believing they are not loyal, whereas the SIEs are dissatisfied with the situations where they are requested to work as 'Japanese' managers, with much lower salaries than the 'Japanese' AEs. That is why it is difficult for SIEs to nurture a dual allegiance." 
Regarding the career anxiety of SIEs, Mr. J (AE, mfg.) claimed:

"We have to understand that SIEs are working with a large amount of anxiety, because their career prospects are not clear. More than that, there is no place for them to be repatriated to when the Chinese subsidiary is closed."

Mr. K (AE, non-mfg.) echoed the view and said:

"In order for Japanese companies to develop and retain SIEs with a dual allegiance, we should alleviate SIEs' anxiety and pressures by presenting clear and broad career opportunities to them."

Table 6: Relationship between social capital/geocentric staffing and dual allegiance

\begin{tabular}{|c|c|}
\hline & $\begin{array}{c}\text { Dual allegiance } \\
\beta\end{array}$ \\
\hline $\begin{array}{l}\text { Control variables } \\
\text { - Type of business } \\
\quad(\mathrm{mfg} .=0, \text { non-mfg. }=1)\end{array}$ & $-0.330 * * *$ \\
\hline $\begin{array}{l}\text { - Type of ownership } \\
\quad(\text { wholly-owned=0, joint-venture }=1)\end{array}$ & $0.275^{* *}$ \\
\hline $\begin{array}{l}\cdot \text { Gender } \\
\quad(\text { male }=0, \text { female }=1)\end{array}$ & -0.002 \\
\hline $\begin{array}{l}\cdot \text { Position } \\
\quad(\text { non-managerial=0, managerial=1) }\end{array}$ & $0.215^{*}$ \\
\hline$\frac{\text { Independent variables }}{\text { - Social capital }}$ & $0.587 * * *$ \\
\hline - Geocentric staffing & $0.276^{* *}$ \\
\hline $\mathrm{R} 2$ & 0.528 \\
\hline $\mathrm{F}$ & $14.899 * * *$ \\
\hline
\end{tabular}

For Hypothesis 4, one of the control variables (gender) was associated with social capital (Table 7). As regards dependent variables, the first factor for normative integration (the 'HRM cycle' approach) was positively associated with 'trust with Japanese AEs' and 'trust with Chinese employees' at the $5 \%$ significance level. We also found the second factor ('interaction with HQ executives' approach) had a positive influence on 'trust with the headquarters in Japan'. More than that, both approaches were correlated with the 
aggregated score of relationship of trust or 'social capital'. Therefore, Hypothesis 4 was supported.

Our informants disclosed their measures to enhance normative integration. For example: "We are now committed to global-wide corporate philosophy training for local staff, including SIEs, in our overseas subsidiaries. The program consists of both Off-JT [off the job training] and On-JT [on the job training] so that the local employees can understand, embody, and diffuse our corporate philosophy. In addition, we dispatch SIE managers to global meetings held at the headquarters in Japan such as global HRM meetings and global marketing meetings where the managers concerned get together from all over the world. We believe such measures contribute to the nurturing of trusting relationships beyond nationalities and places of assignment" (Mr. B, AE, mfg.).

"We have an annual world conference with an award for best practices in embodying our corporate philosophy. Managers around world, including SIEs, attend the conference and share the know-how and experiences, to enhance normative integration. We also conduct a global-wide corporate culture survey to check the dissemination of our corporate philosophy. And, when top executives of the headquarters visit a Chinese subsidiary, we intentionally set up a meeting where capable SIEs can communicate with them" (Mr. A, AE, mfg.).

"Managers at Chinese subsidiaries have to understand global strategies of the headquarters and have strong human networks with the executives there. That is why we give SIE managers opportunities to go on a business trip to Japan and have a face-to-face meeting with the key persons from headquarters" (Mr. L, AE, non-mfg.)

"Our company sends capable local staff (including Japanese SIEs) to the headquarters in Japan for training every year. Through the program, they can realize our global corporate philosophy, internalize our corporate culture, and develop human networks with key persons in the headquarters" (Mr. M. SIE, non-mfg.). 
$\underline{\text { Table 7: Relationship between normative integration and relationship of trust }}$

\begin{tabular}{|c|c|c|c|c|}
\hline & $\begin{array}{c}\text { (a) Trust with } \\
\text { Japanese AEs } \\
\beta\end{array}$ & $\begin{array}{c}\text { (b) Trust with } \\
\text { Chinese } \\
\text { employees } \\
\beta\end{array}$ & $\begin{array}{c}\text { (c) Trust with } \\
\text { the headquarters } \\
\text { in Japan } \\
\beta\end{array}$ & $\begin{array}{c}\text { Social capital } \\
(=\mathbf{a}+\mathbf{b}+\mathbf{c}) \\
\beta\end{array}$ \\
\hline $\begin{array}{l}\text { Control variables } \\
\text { Type of business } \\
\quad(\mathrm{mfg} .=0, \text { non-mfg. }=1)\end{array}$ & 0.205 & -0.054 & -0.069 & 0.016 \\
\hline $\begin{array}{c}\text { - Type of ownership } \\
\text { (wholly-owned=0, } \\
\text { joint-venture=1) }\end{array}$ & 0.114 & -0.069 & 0.099 & 0.072 \\
\hline $\begin{array}{l}\cdot \text { Gender } \\
\quad(\text { male }=0, \text { female }=1)\end{array}$ & $0.239^{*}$ & $0.403^{* *}$ & $0.339^{* *}$ & $0.414 * * *$ \\
\hline $\begin{array}{l}\text { Position } \\
\quad(\text { non-managerial=0, } \\
\text { managerial }=1)\end{array}$ & 0.134 & 0.052 & -0.046 & 0.041 \\
\hline $\begin{array}{l}\text { Independent variables } \\
<\text { Normative integration }> \\
\text { - 'HRM cycle' approach } \\
(\alpha=0.829)\end{array}$ & $0.211^{*}$ & $0.216^{*}$ & 0.095 & $0.204 *$ \\
\hline $\begin{array}{l}\text { 'Interaction with HQ } \\
\text { executives' approach } \\
(\alpha=0.714)\end{array}$ & 0.126 & 0.125 & $0.271^{*}$ & $0.239^{*}$ \\
\hline $\mathrm{R} 2$ & 0.186 & 0.242 & 0.171 & 0.251 \\
\hline $\mathrm{F}$ & $3.044 *$ & $4.247 * *$ & $2.742 *$ & $4.467 * *$ \\
\hline
\end{tabular}

Regarding Hypothesis 5 which tested the relationship between systems integration and global career opportunities, the type of business, one of our control variables, was correlated with geocentric staffing (Table 8). In respect to independent variables, the 'standardization' approach was positively related to 'transfer to other affiliates abroad or those in China' at the $0.1 \%$ significance level, whereas there was a positive association between the 'career advancement opportunities' approach and 'assigned expatriate status or permanent transfer to the HQ in Japan' as well as 'temporary transfer to the HQ in 
Japan'. Our data also revealed that the two factors comprising systems integration have positive influences on the aggregated score of global career opportunities or 'geocentric staffing'. These results provide support for Hypothesis 5.

As far as systems integration and global career opportunities are concerned, Japanese MNEs have a long way to go as our descriptive statistics indicate. Mr. H (AE, non-mfg.) described the differences in HRM between Japanese MNEs and Western MNEs in the following manner:

“Japanese companies pay salary to 'persons' whereas Western companies pay to 'positions' or jobs. This leads to huge status difference between AEs and SIEs in Japanese MNEs. Moreover, 'the place of entry' matters in Japanese companies. Global-wide career opportunities are presented to Japanese employees who were hired by the headquarters as 'global players'. By contrast, the career opportunities for SIEs are very limited because they are regarded as 'local players'."

Likewise, Mr. N (SIE, non-mfg.) explained about his situations from the viewpoints of SIEs:

"It is completely impossible for me to be given an AE status or to be transferred to the headquarters in Japan: the status difference between parent company and subsidiary is too huge to overcome. Japanese companies should present career opportunities to high performers equally, regardless of the places of entry. Now I am thinking of quitting the job as my career prospects for the future are bleak."

Ms. O (SIE, non-mfg.) said:

"I am expected to work the 'Japanese way' by AEs. However, there is no precedent for giving AE status to SIEs in our company. More than that, there are almost no chances of promotion for SIEs. Such situations are very stressful and make me frustrated because my efforts and hard working will not be paid off."

However, some Japanese companies are beginning to innovate their international HRM:

"We have started the reverse transfer of local staff (including SIEs) to the headquarters in Japan. At present, one Japanese SIE manager of a Chinese subsidiary works at the headquarters. We are assured that such opportunities are needed in order for us to attract and retain capable human resources and develop them as global players" (Mr. A, AE, mfg.). 
"One capable SIE at a Chinese subsidiary was transferred to the headquarters in Japan as a full-time employee. When we heard she was hoping to come back to Japan because of her personal reasons, we recommended her to the headquarters. High potentials should not be given to our rivals and should be utilized inside our own global network" (Mr. P, AE, non-mfg.).

Table 8: Relationship between systems integration and global career opportunities

\begin{tabular}{|c|c|c|c|c|}
\hline & $\begin{array}{c}\text { (a) Assigned } \\
\text { expatriate } \\
\text { status or } \\
\text { permanent } \\
\text { transfer to the } \\
\text { HQ in Japan } \\
\beta\end{array}$ & $\begin{array}{c}\text { (b) Temporary } \\
\text { transfer to the } \\
\text { HQ in Japan } \\
\beta\end{array}$ & $\begin{array}{l}\text { (c) Transfer to } \\
\text { other affiliates } \\
\text { abroad or those } \\
\text { in China } \\
\beta\end{array}$ & $\begin{array}{c}\text { Geocentric } \\
\text { staffing } \\
(=\mathbf{a}+\mathbf{b}+\mathbf{c}) \\
\\
\beta\end{array}$ \\
\hline $\begin{array}{l}\text { Control variables } \\
\text { Type of business } \\
\quad(\mathrm{mfg} .=0, \text { non-mfg. }=1)\end{array}$ & 0.187 & 0.003 & $0.231 *$ & $0.212 *$ \\
\hline $\begin{array}{l}\text { - Type of ownership } \\
\text { (wholly-owned=0, } \\
\text { joint-venture=1) }\end{array}$ & -0.064 & -0.157 & 0.034 & -0.078 \\
\hline $\begin{array}{l}\text { - Gender } \\
\quad(\text { male }=0, \text { female }=1)\end{array}$ & -0.192 & 0.032 & 0.158 & -0.010 \\
\hline $\begin{array}{l}\cdot \text { Position } \\
\quad(\text { non-managerial=0, } \\
\text { managerial=1) }\end{array}$ & 0.015 & 0.106 & 0.111 & 0.104 \\
\hline $\begin{array}{c}\text { Independent variables } \\
<\text { Systems integration }> \\
\text { - 'Standardization' } \\
\text { approach }(\alpha=0.835)\end{array}$ & 0.170 & 0.097 & $0.516^{* * *}$ & $0.379 * * *$ \\
\hline $\begin{array}{l}\text { - } C \text { Career advancement } \\
\text { opportunities' } \\
\text { approach }(\alpha=0.764)\end{array}$ & $0.505 * * *$ & $0.466^{* * *}$ & 0.129 & $0.510 * * *$ \\
\hline $\mathrm{R} 2$ & 0.259 & 0.297 & 0.361 & 0.412 \\
\hline
\end{tabular}




\begin{tabular}{|l|l|l|l|l|}
\hline $\mathrm{F}$ & $4.667 * * *$ & $5.645 * * *$ & $7.547 * * *$ & $9.680 * * *$ \\
\hline
\end{tabular}

\section{Discussion}

\section{1. Theoretical implications}

In our review of the relevant literature, we emphasized the importance of organizational context or human resource management in addition to individual skill sets of being bilingual and bicultural for encouraging SIEs to engage in boundary-spanning roles. We developed a new model of antecedents by integrating the theory and findings of prior studies and demonstrated the validity of the model based on a survey of Japaneseaffiliated companies in China. We adopted a new approach to the boundary-spanning roles of SIEs working for a firm from their country of origin, using both individual and organizational perspectives, specifically in the arguably under-studied area of international human resource management. We believe that our model will be particularly relevant to the Chinese operations of Japanese MNEs, given their challenges in human resource management toward both local staff and Japanese assigned expatriates.

SIEs could be valuable resources allowing MNEs to go beyond the AEs/ HCNs dichotomy. These home country SIEs' boundary-spanning function is a vital element of their value to the organization. Our research revealed that normative and systems integration of HRM were associated both with increasing levels of relationships of trust among the parties concerned (social capital) and with global career opportunities for Japanese SIEs (geocentric staffing). Social capital and geocentric staffing had positive influences on the nurturing of dual allegiance. Moreover, we found that dual allegiance, familiarity with local language and culture of SIEs contributed to enhancing their boundary-spanning behavior. Thus, we have been able to uncover the individual and organizational antecedents to effective performance of the boundary-spanning roles of SIEs from both the theoretical and practical points of view.

\section{2. Managerial implications}

The empirical evidence supports our model of determinants of the effective boundaryspanning roles of SIEs. Our results suggest that, at the least, Japanese companies can do much to develop the boundary-spanning roles of SIEs in China. We see no reason to suggest that our findings may not be applicable to other MNEs in other host countries. Regarding normative integration and the relationship of trust, the 'HRM cycle' approach, 
HRM measures which are integrated with the processes of recruitment, training, evaluation, recognition and so on, assist in cultivating social capital between Japanese SIEs and Japanese AEs and between the SIEs and local staff. Meanwhile, our data confirmed that the 'interaction with HQ executives' approach or the opportunities for SIEs to meet face-to-face with the headquarters executives might help promote trusting relationships with headquarters.

As far as systems integration and global career opportunities (geocentric staffing) are concerned, Japanese MNEs have considerable room to standardize their personnel systems and introduce human resource management practices for the career advancement of Japanese SIEs in order to enhance their boundary-spanning roles. In particular, it is noticeable from our descriptive statistics that all the mean scores for global career opportunities for Japanese SIEs were below 2.00. This indicates that in these Japanese MNEs at least it is hard for locally employed people to get onto the international circuit, even when they are Japanese.

Our multiple regression analyses also show that increasing levels of social capital and geocentric staffing are associated with a way of thinking and behavior based on a total optimization of SIEs (which we believe reflects the global mindset literature), and that dual allegiance was positively associated with both of the boundary-spanning functions of SIEs, that is to say, being a bridge between Japanese AEs and Chinese staff and being a bridge between the Chinese subsidiary and the headquarters in Japan. Conversely, it is noteworthy that familiarity with Chinese language and culture are not related to boundary-spanning between the local operation and the headquarters, though those have positive influences on the bridge between Japanese AEs and host country nationals. Such skill sets of SIEs might not necessarily be essential for the bridge with headquarters because AEs and headquarters share the same national language and culture.

Our results seem to verify the importance of dual allegiance or global mindsets and the potential influence of human resource management for SIEs. As suggested by Briscoe and Schuler (2004), those with a dual allegiance at least exhibit the ability to work and communicate in multiple cultures as well as to manage global complexity, contradiction, and conflict. In other words, for the MNEs to cultivate an organizational capability to deal with cultural heterogeneity and strategic complexity or the global integration versus local responsiveness quandary, they require boundary-spanning employees having a dual allegiance. They could be expected to alleviate the dilemmas or trade-offs between 
cultural diversity and between strategic duality by acting as the agents of organizational 'loose coupling' (Schotter et al., 2017).

\section{3. Limitations}

Like all research, this has limitations. Our sampling method could have been more sophisticated. We have single respondents from the companies which might lead to common method bias issues, although the fact that we also conducted a questionnaire survey of Japanese SIEs themselves and demonstrated that the scores of their selfreported Chinese fluency, for example, correspond with those evaluated by the Japanese AEs, reduces the likelihood of that. We confirmed this by conducting a Harman's singlefactor test showing that the first factor explained only $21.0 \%$ of total variance. Additionally, we adopted item order randomization in the questionnaire, and guaranteed anonymity and confidentiality to our respondent companies. The key issue is to get answers from knowledgeable people (Huselid and Becker, 2000) and it seems likely that for many of the issues relating to the boundaries in the firm and people's abilities to cross them, our respondents, as subsidiary presidents, were best placed to answer. We also conducted the semi-structured interview survey of AEs and SIEs of respondent companies for triangulation purposes and the interviews tended to ratify the results of our questionnaire survey. Nevertheless, we recognize the need to obtain data from Chinese employees, particularly Japanese-speaking Chinese employees who also seem to have potential as boundary-spanners for Japanese-affiliates in China. Thus we would encourage future research to deal with the issues.

The evaluations of Japanese SIEs by AEs do not cover all the SIEs working at their companies because they were requested to select 'a maximum of three' of them in the higher positions where they employed four or more SIEs. It would have been too demanding to ask the companies to evaluate all their SIE employees one by one. In addition, the survey method is cross-sectional and longitudinal perspectives would improve future research. We could have used more, and more detailed control variables both for the individuals and the companies. Furthermore, the data is restricted to Japanese MNEs in China and this may impact generalizability.

Despite these limitations, the findings seem robust and this research contributes to the literature on self-initiated expatriation by exploring the antecedents of the boundaryspanning behavior of Japanese SIEs in China from both individual skills and organizational context or human resource management. 


\section{Conclusion}

SIEs could be valuable human resources as boundary-spanners for MNEs because of their familiarity with the language and culture of both parent and host countries, and clearly the utilization of SIEs is an option that could, at least partially, replace the dichotomy of AEs or HCNs. Our empirical survey demonstrated the importance of Japanese SIEs' dual allegiance for their effective boundary-spanning functions. Interestingly enough, this research also revealed that being bilingual and bicultural alone might not be sufficient for them to play the role of bridge between the headquarters in Japan and subsidiaries in China, though the familiarity with Chinese language and culture were positively associated with their boundary-spanning function between Japanese AEs and Chinese employees.

In that sense, Japanese MNEs are failing to benefit fully from this emerging option of using home country SIEs, since all the mean scores of global career opportunities for them, which seem to have positive influences on the nurturing of dual allegiance, or global mindset, were low. The results might imply the necessity of abolishing an unequal 'psychological contract' between the Japanese MNEs and their SIEs, for example, by presenting broader career opportunities to capable SIEs. Amid what some have called the global war for talent (Beechler and Woodward, 2009), understanding the organizational context or appropriate human resource management are important in developing effective bridging functions of home country SIEs.

\section{Acknowledgements}

This work was supported by Japan Society for the Promotion of Science (JSPS) KAKENHI [grant number 16K03914].

\section{References}

Andresen, M., Al Ariss, A., \& Walther, M. (Eds.). (2012). Self-initiated Expatriation: Individual, Organizational, and National Perspectives. New York: Routledge.

Arora, A., Jaju, A., Kefalas, A. G., \& Perenich, T. (2004). An exploratory analysis of global managerial mindsets: A case of U.S. textile and apparel industry. Journal of International Management, 10(3), 393-411. 
Barner-Rasmussen, W., Ehrnrooth, M., Koveshnikov, A., \& Mäkelä, K. (2014). Cultural and language skills as resources for boundary spanning within MNC. Journal of International Business Studies, 45(7), 886-905.

Bartlett, C. A., \& Ghoshal, S. (1989). Managing across Borders: The Transnational Solution. Boston: Harvard Business School Press.

Bartlett, C. A., \& Ghoshal, S. (1995). Transnational Management: Text, Cases, and Readings in Cross-border Management. Chicago: Times Mirror Higher Education Group.

Beechler, S., \& Woodward, I. C. (2009). The global 'war for talent'. Journal of International Management, 15(3), 273-285.

Birkinshaw, J., Ambos, T. C., \& Bouquet, C. (2017). Boundary spanning activities of corporate HQ executives insights from a longitudinal study. Journal of Management Studies, 54(4), 422-454.

Bonache, J., \& Pla-Barber, J. (2005). When are international managers a cost effective solution? The rationale of transaction cost economics applied to staffing decisions in MNCs. Journal of Business Research, 58(10), 1320-1329.

Bonache, J., \& Stirpe, L. (2012). Compensating global employees. In G. K. Stahl, I. Björkman, \& S. Morris (Eds.). Handbook of Research in International Human Resource Management ( $2^{\text {nd }}$ ed., pp. 162-182). Cheltenham: Edward Elgar.

Brannen, M. Y. (2004). When Mickey loses face: Recontextualization, semantic fit, and the semiotics of foreignness. Academy of Management Review, 29(4), 593-616.

Briscoe, D., \& Schuler, R. (2004). International Human Resource Management: Policies and Practices for the Global Enterprise ( $2^{\text {nd }}$ ed.). New York: Routledge.

Bücker, J. \& E. Poutsma (2010). How to assess global management competencies: An investigation of existing instruments. Management Revue, 25(8), 263-291.

Carlile, P. R. (2004). Transferring, translating, and transforming: An integrative framework for managing knowledge across boundaries. Organization Science, 15(5), 555-568.

Collings, D., \& Isichei, M. (2018). The shifting boundaries of global staffing: Integrating global talent management, alternative forms of international assignment and nonemployees into the discussion. International Journal of Human Resource Management, 29(1), 165-187.

Collings, D. G., Scullion, H., \& Morley, M. (2007). Changing patterns of global staffing in the multinational enterprise: Challenges to the conventional expatriate assignment and emerging alternatives. Journal of World Business, 42(2), 198-213.

Doherty, N., \& Dickmann, M. (2012). Self-initiated expatriation: Drivers, employment 
experience, and career outcomes. In M. Andresen, A. Al Ariss, \& M. Walther (Eds.). Self-initiated Expatriation: Individual, Organizational, and National Perspectives (pp. 122-142). New York: Routledge.

Doherty, N., \& Dickmann, M. (2013). Self-initiated and assigned expatriates: Talent management and career considerations. In V. Vaiman, \& A. Haslberger (Eds.). Talent Management of Self-initiated Expatriates: A Neglected Source of Global Talent (pp. 234-255). London: Palgrave Macmillan.

Doherty, N., Dickmann, M., \& Mills, T. (2011). Exploring the motives of companybacked and self-initiated expatriates: International Journal of Human Resource Management, 22(3), 595-611.

Doz, Y. L., Santos, J., \& Williamson, P. (2001). From Global to Metanational: How Companies Win in the Knowledge Economy. Boston: Harvard Business School Press.

Evans, P. (1992). Developing leaders and managing development. European Management Journal, 10(1), 1-9.

Evans, P., Pucik, V., \& Barsoux, J.-L. (2002). The Global Challenge: International Human Resource Management. New York: McGraw-Hill-Irwin.

Evans, P., Pucik, V., \& Björkman, I. (2010). The Global Challenge: International Human Resource Management ( $2^{\text {nd }}$ ed.). New York: McGraw Hill-Irwin.

Fang, Y., Jiang, G.-L. F., Makino, S., \& Beamish, P. W. (2010). Multinational firm knowledge, use of expatriates, and foreign subsidiary performance. Journal of Management Studies, 47(1), 27-54.

Farndale, E., Brewster, C., \& Poutsma, E. (2008). Coordinated vs. liberal market HRM: The impact of institutionalization on multinational firms. International Journal of Human Resource Management, 19(11), 2004-2023.

Fernandez, J. P., \& Barr, M. (1993). The Diversity Advantage: How American Business can Out-perform Japanese and European Companies on the Global Marketplace. New York: Lexington Books.

Froese, F. J. (2012). Motivation and adjustment of self-initiated expatriates: The case of expatriate academics in South Korea. International Journal of Human Resource Management 23(6): 1095-1112.

Furusawa, M. (2008). Global Jintekishigen Kanriron (The Theory of Global Human Resource Management). Tokyo: Hakutou Shobou.

Furusawa, M. (2014). Global talent management in Japanese multinational companies: The case of Nissan Motor Company. In A. Al Ariss (Ed.). Global Talent Management: Challenges, Strategies, and Opportunities (pp.159-170). 
Heidelberg: Springer.

Furusawa, M., \& Brewster, C. (2015). The bi-cultural option for global talent management: The Japanese/ Brazilian Nikkeijin example. Journal of World Business, 50 (1), 133-143.

Furusawa, M., \& Brewster, C. (2016). IHRM and expatriation in Japanese MNEs: HRM practices and their impact on adjustment and job performance. Asia Pacific Journal of Human Resources, 54(4), 396-420.

Furusawa, M., Brewster, C., \& Takashina, T. (2016). Normative and systems integration in human resource management in Japanese multinational companies. Multinational Business Review, 24(2), 82-105.

Gamble, J. (2010). Transferring organizational practices and the dynamics of hybridization: Japanese retail multinationals in China. Journal of Management Studies, 47(4), 705-732.

Gillespie, N. A., \& Mann, L. (2004). Transformational leadership and shared values: The building blocks of trust. Journal of Managerial Psychology, 19(6), 588-607.

Gupta, A. K., \& Govindarajan, V. (2002). Cultivating a global mindset. Academy of Management Executive, 16(1), 116-126.

Hanada, M. (1988). Global-senryaku o sasaeru jinji-system no tenkaihou (How to develop human resource management system supporting global strategy). Diamond Harvard Business, 13(4), 55-64.

Harvey, M., Reiche, B. S., \& Moeller, M. (2011). Developing effective global relationships through staffing with inpatriate managers: The role of interpersonal trust. Journal of International Management, 17(2), 150-161.

Harzing, A.-W., Köster, K., \& Magner, U. (2011). Babel in business: The language barrier and its solution in the HQ-subsidiary relationship. Journal of World Business, 46(3), 279-287.

Harzing, A.-W., \& Pinnington, A. (Eds.). (2011). International Human Resource Management ( $3^{\text {rd }}$ ed.). London: SAGE Publications.

Haslberger, A., \& Brewster, C. (2008). The expatriate family: An international perspective. Journal of Managerial Psychology, 23(3), 324-346.

Hayashi, K. (1985). Ibunka Interface Kanri (Cross Cultural Interface Management). Tokyo: Yuuhikaku.

Hayashi, K. (1994). Ibunka Interface Keiei (Cross Cultural Interface Corporate Management). Tokyo: Nihonkeizaishinbunshuppansha.

Hippler, T., Brewster, C., \& Haslberger, A. (2015). The elephant in the room: The role of time in expatriate adjustment. International Journal of Human Resource 
Management, 26(15), 1920-1935.

Hong, J. F. L., Snell, R. S., \& Easterby-Smith, M. (2006). Cross-cultural influences on organizational learning in MNCS: The case of Japanese companies in China. Journal of International Management, 12(4), 408-429.

Huselid, M. A., \& Becker, B. E. (2000). Comment on 'Measurement error in research on human resources and firm performance: How much error is there and how does it influence effect size estimates' by Gerhart, Wright, McMahan and Snell. Personnel Psychology, 53(4), 835-845.

Japan Institute of Labour (Ed.). (2003). Dai-5-kai Kaigai Haken Kinmusha no Shokugyou to Seikatsu ni kansuru Chosa Kekka (The $5^{\text {th }}$ Survey Results on Work and Life of Assigned Expatriates). Tokyo: Japan Institute of Labour.

Javidan, M., \& Teagarden, M. B. (2011). Conceptualizing and measuring global mindset. In J. S. Osland, M. E. Mendenhall, \& M. Li (Eds.). Advances in Global Leadership, Vol. 10 (pp. 13-39). Bingley, UK: Emerald Group Publishing Limited.

Kane, A. A., \& Levina, N. (2017). 'Am I still one of them?': Bicultural immigrant managers navigating social identity threats when spanning global boundaries. Journal of Management Studies, 54(4), 540-577.

Kedia, B. L., \& Mukherji, A. (1999). Global managers: Developing a mindset for global competitiveness. Journal of World Business, 34(3), 230-251.

Khatri, N., Fern C. T., \& Budhwar, P. (2001). Explaining employee turnover in an Asian context. Human Resource Management Journal, 11(1), 54-74.

Kosonen, R., Kettunen, E., \& Penttilä, A. (2012). Challeges of Finnish and Japanese companies in the Chinese business environment: Relations with the local labour force, CEMAT Papers, 1/2012, 1-47.

Kraimer, M., Bolino, M., \& Mead, B. (2016). Themes in expatriate and repatriate research over four decades: What do we know and what do we still need to learn? Annual Review of Organizational Psychology and Organizational Behavior, 3, 83-109.

Lazarova, M., Westman, M., \& Shaffer, M. A. (2010). Elucidating the positive side of the work-family interface on international assignments: A model of expatriate work and family performance. Academy of Management Review, 35(1), 93-117.

Lee, C. H. (2005). A study of underemployment among self-initiated expatriates. Journal of World Business, 40(2), 172-187.

Levy, O., Beechler, S., Taylor, S., \& Boyacigiller, N. A. (2007). What we talk about when we talk about 'global mindset': Managerial cognition in multinational corporations. Journal of International Business Studies, 38(2), 231-258.

Mäkelä, K., \& Brewster, C. (2009). Interunit interaction contexts, interpersonal social 
capital, and differing levels of knowledge sharing. Human Resource Management, 48( 4), 591-614.

Mäkelä, K., \& Suutari, V. (2013). The social capital of traditional and self-initiated expatriates. In V. Vaiman, \& A. Haslberger (Eds.). Talent Management of Selfinitiated Expatriates: A Neglected Source of Global Talent (pp. 256-277). London: Palgrave Macmillan.

Martin, D. C., \& Bartolk, K. M. (2003). Factors influencing expatriate performance appraisal system success: An organizational perspective. Journal of International Management, 9(2), 115-132.

Ministry of Foreign Affairs of Japan (2017). Kaigai Zairyuu Houjinsuu Chousa Toukei: Heisei 29-nen-ban (Annual Report of Statistics on Japanese Nationals Overseas: 2017 version). Tokyo: Ministry of Foreign Affairs of Japan.

Murray, J. Y., \& Fu, F. Q. (2016). Strategic guanxi orientation: How to manage distribution channels in China? Journal of International Management, 22(1), 116.

Okamoto, K., \& Teo, S. T. T. (2012). Role stress reduction and cultural mediators in overseas Japanese companies. International Journal of Human Resource Management, 23(17), 3522-3635.

Peltokorpi, V., \& Froese, F. J. (2012). Differences in self-initiated and organizational expatriates' cross-cultural adjustment. In M. Andresen, A. Al Ariss, \& M. Walther (Eds.). Self-initiated Expatriation: Individual, Organizational, and National Perspectives (pp. 90-104). New York: Routledge.

Perlmutter, H. V. (1969). The tortuous evolution of the multinational corporation. Columbia Journal of World Business, 4(1), 9-18.

Roberts, M. J. D., \& Beamish, P. W. (2017). The scaffolding activities of international returnee executives: A learning based perspective of global boundary spanning. Journal of Management Studies, 54(4), 511-539.

Rousseau, D. M., Sitkin, S. B., Burt, R. S., \& Camerer, C. (1998). Not so different after all: A cross-discipline view of trust. Academy of Management Review, 23(3), 393404.

Rui, H., Zhang, M., \& Shipman, A. (2017). Chinese expatriate management in emerging markets: A competitive advantage perspective. Journal of International Management, 23(2), 124-138.

Sakai, J. (2004). The Clash of Economic Cultures: Japanese Bankers in the City of London. London: Routledge.

Schotter, A., \& Abdelzaher, D. (2013). The boundary spanning effects of the Muslim 
diaspora on the internationalization processes of firms from Organization of Islamic Conference Countries. Journal of International Management, 19(1), 8298.

Schotter, A., \& Beamish, P. W. (2011). Performance effect of MNC headquarterssubsidiary conflict and the role of boundary spaners: The case of headquarter initiative rejection. Journal of International Management, 17(3), 243-259.

Schotter, A. P. J., Mudambi, R., Doz, Y. L., \& Gaur, A. (2017). Boundary spanning in global organizations. Journal of Management Studies, 54(4), 403-412.

Scullion, H., \& Collings, D. G. (2006). Global staffing. London: Routledge.

Selmer, J. (2004). Expatriates' hesitation and the localization of Western business operations in China. International Journal of Human Resource Management, 15(6), 1094-1107.

Selmer, J. (2006). Language and adjustment: Western expatriates in China. Thunderbird International Business Review, 48 (3), 347-368.

Stahl, G. K., Björkman, I., \& Morris, S. (2012). Introduction. In G. K. Stahl, I. Bjorkman, \& S. Morris (Eds.). Handbook of Research in International Human Resource Management ( $2^{\text {nd }}$ ed., pp. 1-12). Cheltenham: Edward Elgar.

Suutari, V., \& Brewster, C. (2000). Making their own way: International experience through self-initiated foreign assignments. Journal of World Business, 35(4), 417436.

Suutari, V., Brewster, C., \& Dickmann, M. (2018). Contrasting assigned expatriates and self-initiated expatriates: A review of extant research and a future research agenda. In M. Dickmann, V. Suutari, \& O. Wurtz (Eds.). The Management of Global Careers: Exploring the Rise of International Work (pp. 63-89). London: Springer International.

Taura, R. (2005). Japanese company's HRM strategies in China, NRI Papers, 86, 1-10.

Teng, L., Huang, D., \& Pan, Y. (2017). The performance of MNE subsidiaries in China: Does it matter to be close to the political or business hub? Journal of International Management, 23(3), 292-305.

Thang, L. L., MacLachlan, E., \& Goda, M. (2006). Living in 'my space': Japanese working women in Singapore. Chiri-Kagaku (Geographical Sciences), 61(3), 156-171.

Thomas, D., \& Lazarova, M. (2014). Managing People Globally: Essentials of International Human Resource Management. Thousand Oaks, CA: Sage Publications.

Tymon, W. G., Stumpf, S. A., \& Doh, J. P. (2010). Exploring talent management in India: 
The neglected role of intrinsic rewards. Journal of World Business, 45(2), 109121.

Vaiman, V., \& Haslberger, H. (Eds.). (2013). Talent Management of Self-initiated Expatriates: A Neglected Source of Global Talent. London: Palgrave Macmillan.

Varma, A., Budhwar, P., \& Pichler, S. (2011). Chinese host country nationals' willingness to help expatriates: The role of social categorization. Thunderbird International Business Review, 53(3), 353-364.

Vora, D., Kostova, T., \& Roth, K. (2007). Roles of subsidiary managers in multinational corporations: The effect of dual organizational identification. Management International Review, 47(4), 595-620.

Wang, X., \& Nayir, D. Z. (2006). How and when is social networking important? Comparing European expatriate adjustment in China and Turkey. Journal of International Management, 12(4), 449-472.

Yagi, N., \& Kleinberg, J. (2011). Boundary work: An interpretive ethnographic perspective on negotiating and leveraging cross-cultural identity. Journal of International Business Studies, 42(5), 629-653.

Yoshino, M. Y. (1976). Japan's Multinational Enterprises. Cambridge, MS: Harvard University Press. 


\section{Appendices}

$\underline{\text { Appendix 1: Factor analysis of practices for normative integration }}$

\begin{tabular}{|l|l|l|l|}
\hline Practices & Factor 1 & Factor 2. & h2 \\
\hline $\begin{array}{l}\text { The training program of our corporate philosophy is implemented for } \\
\text { Japanese self-initiated expatriates. }\end{array}$ & 0.828 & -0.120 & 0.673 \\
\hline $\begin{array}{l}\text { When hiring Japanese self-initiated expatriates locally, such recruitment } \\
\text { policy is in place that includes the candidates' compatibility with our } \\
\text { corporate philosophy (potentials to accept our corporate philosophy) } \\
\text { within the hiring criteria. }\end{array}$ & 0.752 & 0.057 & 0.580 \\
\hline $\begin{array}{l}\text { There is a recognition program and in-house events which reflect our } \\
\text { corporate philosophy. }\end{array}$ & 0.749 & -0.067 & 0.551 \\
\hline $\begin{array}{l}\text { Such personnel evaluation policy is in place that incorporates the } \\
\text { embodiment of our corporate philosophy (the way of thinking and } \\
\text { behavior based on our corporate philosophy) as a criteria to evaluate } \\
\text { Japanese self-initiated expatriates. }\end{array}$ & 0.692 & 0.083 & 0.502 \\
\hline $\begin{array}{l}\text { The level of infiltration of our corporate philosophy among Japanese self- } \\
\text { initiated expatriates is checked through regular employee satisfaction and } \\
\text { corporate culture surveys. }\end{array}$ & 0.494 & 0.109 & 0.270 \\
\hline $\begin{array}{l}\text { Japanese self-initiated expatriates are invited to attend meetings or events } \\
\text { with the executives from the headquarters when they visit China. }\end{array}$ & -0.102 & 0.806 & 0.637 \\
\hline $\begin{array}{l}\text { Japanese self-initiated expatriates are given opportunities to go on a } \\
\text { business trip to Japan to get in touch with key persons at the headquarters } \\
\text { in Japan. }\end{array}$ & 0.158 & 0.695 & 0.538 \\
\hline Eigenvalue & 3.086 & 1.529 & 21.8 \\
\hline Contribution (\%) & 44.1 & 0.714 & \\
\hline Cronbach's alpha & 0.829 & \\
\hline
\end{tabular}


Appendix 2: Factor analysis of practices for systems integration

\begin{tabular}{|l|l|l|l|}
\hline Practices & Factor 1 & Factor 2. & h2 \\
\hline The personnel evaluation system is standardized worldwide. & 0.937 & 0.039 & 0.887 \\
\hline $\begin{array}{l}\text { The compensation system is standardized worldwide. } \\
\begin{array}{l}\text { The grading system such as ability-based grade system or job grade system } \\
\text { for employees is standardized worldwide. }\end{array}\end{array}$ & 0.736 & -0.074 & 0.534 \\
\hline $\begin{array}{l}\text { There are programs or systems such as succession planning and/ or talent } \\
\text { management in place to list competent Japanese SIEs at the headquarters } \\
\text { in Japan to develop and utilize them as the future candidates for executive } \\
\text { positions. }\end{array}$ & -0.084 & 0.057 & 0.531 \\
\hline The career path is clearly presented for competent Japanese SIEs. & 0.029 & 0.732 \\
\hline $\begin{array}{l}\text { There is an in-house global job-posting system in place which allows } \\
\text { Japanese SIEs to apply. }\end{array}$ & 0.080 & 0.542 \\
\hline Eigenvalue & 0.570 & 0.767 \\
\hline Contribution (\%) & 2.422 & 1.913 \\
\hline Cronbach's alpha & $40.4 \%$ & $31.9 \%$ \\
\hline
\end{tabular}




\begin{tabular}{|c|c|c|c|c|c|c|c|c|c|c|c|c|c|c|c|c|c|}
\hline & Mean & SD & 1 & 2 & 3 & 4 & 5 & 6 & 7 & 8 & 9 & 10 & 11 & 12 & 13 & 14 & 15 \\
\hline $\begin{array}{l}\text { 1. Type of business } \\
(\mathrm{mfg}=0 \text {, non-mfg. }=1) \\
*^{*} \text { control variable }\end{array}$ & 0.51 & 0.503 & - & & & & & & & & & & & & & & \\
\hline $\begin{array}{l}\text { 2. Type of ownership } \\
\text { (wholly-owned }=0 \text {, } \\
\text { joint-venture }=1 \text { ) } \\
\text { *control variable }\end{array}$ & 0.18 & 0.383 & $0.399 * * *$ & - & & & & & & & & & & & & & \\
\hline $\begin{array}{l}\text { 3. Gender } \\
(\text { male }=0 \text {, female }=1) \\
*_{\text {control variable }}\end{array}$ & 0.31 & 0.464 & $0.278^{* * *}$ & -0.058 & - & & & & & & & & & & & & \\
\hline $\begin{array}{l}\text { 4. Position } \\
\text { (non-managerial }=0 \text {, } \\
\text { managerial }=1 \text { ) } \\
*_{\text {control variable }} \\
\end{array}$ & 0.62 & 0.489 & -0.104 & -0.169 & $-0.354 * *$ & - & & & & & & & & & & & \\
\hline 5. Global mindset & 3.11 & 1.090 & -0.103 & 0.033 & 0.086 & $0.268^{*}$ & - & & & & & & & & & & \\
\hline $\begin{array}{l}\text { 6. Chinese language } \\
\text { proficiency }\end{array}$ & 4.06 & 1.084 & 0.044 & $-0.268^{*}$ & $0.293 * *$ & -0.038 & -0.025 & - & & & & & & & & & \\
\hline $\begin{array}{l}\text { 7. Familiarity with } \\
\text { Chinese culture }\end{array}$ & 2.57 & 1.188 & $0.223 *$ & \begin{tabular}{|l|}
-0.038 \\
\end{tabular} & $0.386^{* * * *}$ & -0.051 & $0.209^{*}$ & $0.329^{* * *}$ & - & & & & & & & & \\
\hline $\begin{array}{l}\text { 8. Bridge between } \\
\text { AEs and local staff }\end{array}$ & 3.33 & 1.248 & $0.263^{*}$ & 0.110 & $0.360^{* * * *}$ & -0.027 & $0.243^{*}$ & $0.450^{* * * *}$ & $0.671^{* * * *}$ & - & & & & & & & \\
\hline $\begin{array}{l}\text { 9. Bridge between } \\
\text { Chinese subsidiary } \\
\text { and the headquarters }\end{array}$ & 3.03 & 1.370 & 0.137 & 0.201 & $0.333^{* *}$ & 0.003 & $0.548 * * *$ & 0.071 & $0.282^{* * *}$ & $0.423 * * *$ & - & & & & & & \\
\hline 10.. Social capital & 3.89 & 0.696 & 0.108 & -0.066 & $0.370^{* * * *}$ & 0.038 & $0.597 * * * *$ & $0.260^{*}$ & $0.334 * *$ & $0.422 * * *$ & $0.560 * *$ & - & & & & & \\
\hline 11. Geocentric staffing & 1.72 & 0.653 & 0.123 & -0.081 & 0.131 & 0.109 & $0.210^{*}$ & 0.065 & $0.275^{* * *}$ & $0.356 * *$ & 0.159 & 0.026 & - & & & & \\
\hline $\begin{array}{l}\text { 12. 'HRM cycle' approach } \\
\text { *factor } 1 \text { for normative } \\
\text { Integration }\end{array}$ & 3.16 & 0.834 & -0.121 & \begin{tabular}{|l|}
-0.129 \\
\end{tabular} & 0.058 & 0.105 & 0.206 & 0.112 & 0.165 & $0.232 *$ & 0.029 & 0.150 & $0.246^{*}$ & - & & & \\
\hline $\begin{array}{l}\text { 13. 'Interaction with } \\
\text { HQ executives' approach } \\
\text { *factor } 2 \text { for normative } \\
\text { integration }\end{array}$ & 3.32 & 0.944 & -0.185 & $-0.329 * *$ & $-0 / 078$ & $0.345^{* *}$ & $0.262^{*}$ & 0.013 & 0.169 & 0.168 & 0.185 & 0.168 & $0.276 * *$ & 0.035 & - & & \\
\hline $\begin{array}{l}\text { 14. 'Standardization' approach } \\
\text { *factor } 1 \text { for systems } \\
\text { integration }\end{array}$ & 1.51 & 0.721 & 0.018 & \begin{tabular}{|l|}
0.088 \\
\end{tabular} & -0.197 & $0.267^{*}$ & $0.310^{* * *}$ & 0.038 & -0.182 & 0.034 & 0.107 & 0.145 & $0.266^{*}$ & 0.109 & 0.092 & - & \\
\hline $\begin{array}{l}\text { 15. 'Career advancement } \\
\text { opportunities' approach } \\
\text { *factor } 2 \text { for systems } \\
\text { integration }\end{array}$ & 2.11 & 0.860 & -0.040 & $-0.226^{*}$ & $0.381 * * *$ & -0.113 & 0.173 & $0.363^{* * *}$ & $0.539^{* * *}$ & $0.526 * * *$ & $0.258^{*}$ & 0.172 & $0.493 * * *$ & $0.214^{*}$ & $0.258^{*}$ & -0.148 & - \\
\hline
\end{tabular}

*** $: \mathrm{p}<0.001, * *: \mathrm{p}<0.01, *: \mathrm{p}<0.05$. 
${ }^{\mathrm{i}}$ In multiple regression analyses, we eliminated four cases having a missing value. 